\title{
DARURAT KEBIJAKAN PEMENUHAN KEBUTUHAN HASIL SUMBER DAYA ALAM DI PASAR DALAM NEGERI
}

(Policy Emergency of Meeting the Needs of Natural Resources Products in Domestic Market)

\author{
Ahmad Redi \\ Fakultas Hukum Universitas Tarumanagara (UNTAR) \\ Jl. S Parman No.1 Grogol, Jakarta Barat \\ Email: ahmadr@fh.untar.ac.id
}

Naskah diterima: 5 Juni 2015; revisi: 10 Agustus 2015; disetujui: 19 Agustus 2015

\begin{abstract}
Abstrak
Liberalisasi ekonomi berdampak pada liberalisasi produk sumber daya alam (SDA) Indonesia. Produk SDA secara ideal diprioritaskan terlebih dahulu untuk pemenuhan kebutuhan dalam negeri sebelum diliberalisasi di pasar bebas karena menyangkut ketahanan nasional Indonesia.Tulisan ini akan melakukan kajian mengenai: 1. Bagaimanakah pengaturan kewajiban pemenuhan kebutuhan dalam negeri atas komoditas sumber daya alam di Indonesia? dan 2. Hambatan dan tantangan apa saja yang mungkin timbul atas kewajiban pemenuhan kebutuhan dalam negeri dalam rangka ketahanan nasional? Metode penelitian yang digunakan yaitu metode penelitian hukum normatif. Adapun jawaban permasalahan tersebut, pertama, peraturan perundang-undangan bidang SDA ada yang telah mengatur mengenai pemenuhan kebutuhan dalam negeri, tetapi ada pula peraturan perundang-undangan yang tidak mengatur. Kedua, hambatan pemenuhan kebutuhan dalam negeri atas hasil sumber daya alam meliputi hambatan regulasi, implementasi, dan kapasitas. Lalu tantangannya, meliputi tantangan perkembangan paham liberalisasi, komodifikasi SDA, dan ketahanan SDA. Adapun saran dari hasil kajian ini, antara lain pembuat kebijakan harus menentukan secara ketat komoditas SDA yang akan diekspor; mengurangi bahkan menghilangkan ekspor bahan mentah; dan tegas kepada pelaku usaha untuk memenuhi kewajiban pemenuhan kebutuhan dalam negeri.
\end{abstract}

Kata kunci: kebutuhan dalam negeri, SDA, pasar

\section{Abstract}

Economic liberalization made impact on natural resources product's liberalization in Indonesia. Natural resources products are ideally prioritized to meet domestic needs before they are liberalized in the free market because they strategically influence Indonesia's national resilience. This article will carry out assessment on: (1) How is the regulating obligation of meeting domestic need for Indonesia natural resources commodity products?; and (2) What obstacles and challenges that might arise on this obligation of meeting domestic need in the frame of national resilience? The research use normative legal research method. The research's finding are, first, some of the legislative regulations on natural resources have ruled on meeting the domestic need, however, there are others which have not. Second, the obstacles of meeting domestic need for natural resources products include obstacles of regulation, implementation, and capacity. The challenges include the challenge of liberalization idea development and natural resources resilience. The recommendation of this assessment is that the policy makers must set up regulation firmly on which natural resources product is exported, lowering or even erasing raw material export and act firmly to the business actors in fulfilling the obligation of meeting domestic needs.

Keywords: domestic needs, natural resources, market 


\section{A. PENDAHULUAN}

Globalisasi di segala bidang telah dimulai pada akhir abad ke 19 dan awal abad ke 20 yang saat ini masih terus berlangsung di berbagai belahan dunia. Proses integrasi secara global (globalisasi) terjadi karena adanya pertukaran pemikiran, budaya, serta pertukaran barang dan jasa. Hal tersebut semakin didorong oleh masifnya perkembangan teknologi komunikasi dan informasi yang berdampak pada bergesernya tatanan dunia seolah menjadi global village yang tidak tersekat lagi batas-batas teritorial. Hubungan antar negara menjadi hubungan yang saling ketergantungan (interdepedensi) dalam memenuhi berbagai kebutuhan masing-masing negara. ${ }^{1}$ Lebih lanjut Stela Dima manyampaikan bahwa:

"The most common definition of globalisation refers to the growth of economic activity across national and regional boundaries. It refers as well, to an increased movement of tangible and intangible factors: people via migration, goods and services, through trade and investments". ${ }^{2}$

Selanjutnya IMF merilis bahwa terdapat 4 (empat) aspek yang terglobalisasi secara ekonomi, yaitu: (1) trade; (2) capital movement; (3) movement of people; (4) spread of knowledge (and technology). ${ }^{3}$ Terhadap aspek pertama yaitu perdagangan (trade) di negaranegara berkembang yang termasuk ke dalam negara the newly industrialized economies (NIEs) perdagangan internasional menjadi hal yang sangat penting dalam mendukung perekonomian nasionalnya. Kegiatan ekspor menjadi bentuk perdagangan internasional yang marak dilakukan. Adapun komoditas yang diekspor merupakan komoditas primer misalnya makanan dan bahan mentah (raw materials) yang biasanya diproduksi oleh negara-negara berkembang untuk selanjutnya diolah oleh negara-negara maju.

Kegiatan ekspor terhadap komoditas bahan mentah merupakan salah satu kegiatan ekonomi yang saat ini masih menjadi primadona di Indonesia. Ekspor akan berkaitan dengan pertumbuhan ekonomi suatu negara dan juga sangat terkait pula dengan kebutuhan dalam negeri. Di Cina, pertumbuhan ekonomi akan meningkatkan ekspor dan permintaan domestik.

"Exports and domestic demand are both important for economic growth in China. More specifically, domestic household and government consumption are important for economic growth. Moreover, economic growth will increase exports and domestic demand. There is no evidence that exports or domestic demand is superior to each other and therefore, a balance emphasises on the role of exports and domestic demand is important for successful and sustained economic growth" ${ }^{4}$

Tidak hanya sektor ekspor saja, kegiatan globalisasi di Indonesia atas sumber daya alam dilakukan pula melalui kegiatan investasi asing di Indonesia. Investasi langsung ataupun tidak langsung, secara riil telah mampu meningkatkan 
perekonomian suatu negara. Meningkatnya perekonomian di berbagai negara di dunia cenderung membawa perubahan positif bagi kehidupan berbangsa dan bernegara. Pertumbuhan perekonomian di suatu negara, termasuk Indonesia akan berdampak pada laju pertumbuhan pembangunan yang signifikan, berkurangnya tingkat pengangguran, semakin berkurangnya tingkat kemiskinan, dan majunya pendidikan serta baiknya standar kesehatan masyarakat. Walau dalam interaksi global seringkali terjadi fluktuasi hubungan sebagaimana pertumbuhan ekonomi domestik yang fluktuatif serta pengaruh ketergantungan dalam integrasi antara negara yang berbedabeda. $^{5}$

Salah satu aspek yang mempengaruhi peningkatan perekonomian suatu negara, misalnya dalam pengelolaan sumber daya alam yang dipengaruhi oleh laju penanaman modal asing di negara tersebut, sebagaimana pendapat Richard M Auty: ${ }^{6}$

"An abundance of natural resources should accelerate economic development because it increases exports so that more capital goods can be imported to build up the economy, and also because the natural resource rents (returns in excess of those required by an efficient producer) can be used to boost capital investment".

Globalisasi ekonomi melalui penanaman modal asing, ${ }^{7}$ akan berdampak pula pada penyerapan tenaga kerja, alih teknologi ke dalam negeri, penerimaan negara melalui pajak dan penerimaan bukan pajak (royalti, iuran, dan jenis pendapatan lainnya), sehingga idealnya globalisasi ekonomi akan memberikan sebesarbesar bagi kemakmuran rakyat.

Kebutuhan akan investasi tidak dapat dipungkiri karena kebutuhan dana untuk pembangunan sangat besar. Selain daritabungan dalam negeri, pembiayaan pembangunan perlu pula dilengkapi dengan penanaman modal dari luar negeri, khususnya untuk bidang usaha yang bersifat padat modal dan berisiko tinggi atau penuh ketidakpatian (uncertainty); memerlukan keterampilan (skill), dan teknologi, seperti pengembangan sumber daya alam. ${ }^{8}$ Selain faktor sosial ekonomi tersebut, faktor politik negara tuan rumah tempat keberadaan sumber daya alam seperti mineral dan batubara, minyak dan gas bumi, atau panas bumi menjadi faktor penting yang akan mempengaruhi investasi asing. ${ }^{9}$

5 Sabina Tuca, "The Evolution Of Economic Globalization During The Current Global Crisis", CES Working Papers -Volume V, Issue 4, hlm. 647.

6 Richard M Auty, “Natural Resources, Development Models and Sustainable Development”, (Makalah disampaikan pada pada seminar oleh International Institute for Environment and Development, 01 June 2003).

7 Dalam Undang-Undang Nomor 25 Tahun 2007 tentang Penanaman Modal mengenai tujuan penanaman modal, antara lain untuk: meningkatkan pertumbuhan ekonomi nasional, menciptakan lapangan kerja, meningkatkan pembangunan ekonomi berkelanjutan, meningkatkan kemampuan daya saing dunia usaha nasional, meningkatkan kapasitas dan kemampuan teknologi nasional, mendorong pengembangan ekonomi kerakyatan, mengolah ekonomi potensial menjadi kekuatan ekonomi riil dengan menggunakan dana yang berasal, baik dari dalam negeri maupun dari luar negeri, dan meningkatkan kesejahteraan masyarakat.

8 Madjedi Hasan, Kontrak Minyak dan Gas Bumi Berasas Keadilan dan Kepastian Hukum, (Jakarta: PT Fikahati Aneska, 2009), hlm. 1.

9 Akinkugbe 0, "Flow of Foreign Direct Investment to Higher to Neglected Developing Countries" (Discussion Paper No. 2003/02 oleh World Institute for Development Economic Research (WIDER), United Nations University, 2003). 
Adanya kesulitan mendapatkan akses permodalan untuk membiayai proyek yang berisiko tinggi (hight risk capital) dan kebutuhan akan keterampilan yang diperlukan dalam eksplorasi dan eksploitasi telah mengakibatkan banyak proyek pengusahaan sumber daya alam, misalnya minyak dan gas bumi di sektor hulu di negara-negara berkembang dibiayai oleh perusahaan minyak dan gas bumi dari asing ${ }^{10}$ yang selanjutnya perolehan keuntungannya negara didapat melalui mekanisme bagi hasil (production sharing) setelah suatu kegiatan hulu migas telah berproduksi atau dapat pula melalui mekanisme royalti, pajak, iuran produksi, iuran tetap, bea masuk dan cukai, iuran eksplorasi, pajak daerah dan retribusi daerah. Mekanisme bagi hasil di sektor migas menjadi bagian daricost recovery. ${ }^{11}$ Bahkan dalam perkembangannya, Indonesia mulai mampu memiliki komposisi maksimal pengelolaan blok migas seperti Blok Mahakam. Pengelolaan dominan ini didasari oleh adanya keinginan kedaulatan dan kemandirian energi yang sedimikian lama hanya menjadi wacana. ${ }^{12}$ Begitu pula di sektor sumber daya alam lainnya, misalnya kehutanan dan perkebunan yang memerlukan modal yang besar untuk pengusahaannya.

Melalui penanaman modal asing di bidang sumber daya alam maka akan terjadi pula produksi atas komoditas sumber daya alam, misalnya mineral, batubara, minyak bumi, gas bumi, kayu, biji sawit, dan karet. Komoditas

10 W Khadduri, "Facilitating Investment in Energy Sector" (Makalah disampaikan pada the $8^{\text {th }}$ International Energy Forum, September 21-23, 2002, Osaka, Japan oleh Middle East Economic Survey).

11 Cost Recovery adalah bagian Pemerintah yang diperoleh dari bagi hasil produksi minyak dan gas bumi yang dikerjakan oleh kontraktor. Pemerintah dalam melaksanakan kegiatan pertambangan tidak memiliki dana yang besar, padahal sektor tambang merupakan sektor yang dalam kegiatan eksplorasi dan eksploitasinya memerlukan dana yang besar kerena kebutuhan teknologi yang canggih sehingga pembiayaanya tidak dapat serta merta dibiayai oleh negara. Untuk melaksanakan kegiatan eksplorasi dan eksploitasi minyak dan gas bumi oleh kontraktor, maka diberlakukan sistem melalui skema kontraktor membiayai semua kegiatan eksplorasi dan eksploitasi migas, yang apabila wilayah kontrak tersebut telah berproduksi maka Pemerintah mendapatkan bagi hasil dari produksi tersebut.

Terdapat 3 (tiga) skema dalam melakukan kegiatan usaha hulu minyak dan gas bumi, yaitu dengan: 1. Production Sharing Contract, skema ini dilakukan diantaranya oleh Indonesia, Malaysia, India, Qatar, Rusia, dan Ploandia; 2. Risk Service Contract, skema ini dilakukan diantaranya Iran, Arab Saudi, Brazil, Venezuela, dan Nigeria; 3. Concession/ License, skema ini dilakukan diantaranya Dubai, Australia, Argentina, Inggris, Spanyol, Prancis, Canada, dan USA. (Lihat Madjedi Hasan, hlm. 52-53).

Di Indonesia, untuk mengatur cost recovery, Pemerintah telah menerbitkan Peraturan Pemerintah Nomor 79 Tahun 2010 tentang Biaya Operasi Yang Dapat Dikembalikan dan Perlakukan Pajak Penghasilan di Bidang Hulu Minyak dan Gas Bumi. Dalam Bagian Penjelasan Umum Peraturan Pemerintah tersebut, dijelaskan beberapa hal, yaitu:

- biaya yang dapat dikurangkan dari penghasilan bruto akan sama dengan biaya yang dapat dikembalikan oleh Pemerintah;

- jenis, syarat, metode alokasi, dan batasan jumlah dari biaya tersebut akan diatur secara seksama agar penerimaan negara lebih optimal dan agar tercipta kepastian hukum;

- pajak-pajak tidak langsung seperti pajak pertambahan nilai (PPN), bea masuk, pajak bumi dan bangunan (PBB), pajak daerah dan retribusi daerah yang selama ini menjadi beban Pemerintah diubah sehingga menjadi beban bersama Pemerintah dan kontraktor dengan cara membukukan pembayaran pajak tidak langsung tersebut sebagai komponen biaya;

- kontraktor diwajibkan membayar sendiri pajak penghasilan yang terutang atas penghasilan yang diterima atau diperoleh di luar skema kontrak kerja sama.

12 The Geotime Magazine, "Sengkarut Blok Mahakam", Vol 02 Nomor 16, 29 Juni-5 Juli 2015, hlm. 28. 
tersebut yang berupa bahan mentah pun diekspor ke luar negeri untuk memenuhi kebutuhan dunia akan bahan mentah yang kemudian diolah sehingga menjadi produk jadi.

Indonesia merupakan negara salah satu eksportir terbesar raw materials di dunia. Menurut Richard Dutu:

"Indonesia abounds with natural resources. It is the world's largest exporter of steam coal, refined tin and (until the enforcement of the export ban earlier this year) nickel ore. It is also a leading exporter of gold, bauxite, lead, zinc and copper. Its potential in renewable resources is also huge. It has become the world's number one palm oil producer and exporter. In addition, it is the secondlargest producer of rubber, robusta coffee and fisheries products, and holds $40 \%$ of the world's geothermal energy reserves". ${ }^{13}$

Indonesia memiliki pula tambang terbesar di dunia, yaitu Grasberg Gold Mine yang dieksplorasi dan dieksploitasi (operasi produksi) oleh PT Freeport yang sahamnya mayoritas dimiliki oleh Freeport-McMorran Copper \& Gold yang mengekspor konsentrat mineral berupa emas, tembaga, dan perak, ${ }^{14} 10$ (sepuluh) besar negara penghasil tembaga, urutan ke-17 (tujuh belas) penghasil perak terbesar di dunia, dan urutan ke-2 (kedua) penghasil nikel terbesar di dunia. Untuk nikel walaupun/Indonesia merupakan negara terbesar ke-2 (kedua) penghasil nikel namun bukan nikel olahan yang diproduksi namun masih dalam bentuk bahan mentah. Untuk bauksit, walaupun Indonesia merupakan salah satu negara terbesar yang memiliki tambang bauksit namun Indonesia bukanlah negara penghasil alumunium terbesar di dunia karena bauksit (raw material) yang merupakan bahan baku alumunium masih dialokasikan untuk pasar ekspor. Sebagian besar komoditas tersebut diekspor dalam bentuk bahan mentah.

Pada era liberalisasi perdagangan yang merupakan dampak dari globalisasi ekonomi, komoditas sumber daya alam Indonesia diekspor ke luar negeri dalam bentuk bahan mentah yang dengan adanya ekspor bahan mentah tersebut, nilai tambah produk tidak dapat dirasakan oleh Indonesia. Padahal di sisi lain, ekspor atas bahan mentah tersebut dapat menimbulkan persoalan pasokan dalam negeri. Sumber daya alam yang diekspor merupakan sumber daya alam yang tidak dapat diperbaharui (non renewable). Artinya apabila sumber daya alam tersebut berkurang dan habis maka ketahanan sumber daya alam Indonesia akan lemah. Masalah krisis hasil sumber daya alam tersebut akan berdampak pada kehidupan bangsa Indonesia sebagaimana saat ini terjadi di sektor minyak bumi, padahal di masa lalu Indonesia merupakan salah satu negara yang memiliki produksi minyak bumi yang besar namun karena ekspor besar-besaran, saat ini Indonesia mengalami defisit pasokan minyak untuk kebutuhan nasional.

Sederhananya produksi minyak tahunan yang lebih besar dibanding penemuan cadangan minyak baru menyebabkan berkurangnya

13 Ricard Dutu, "Making the Most of Natural Resources in Indonesia”, OECD Economics Department Working Papers No. 1236, 28 May 2015, hlm. 7.

14 Urutan 10 (sepuluh) tambang emas terbesar di dunia, yaitu: 1. Graberg Gold Mie (Papua, Indonesia), 2. Maruntu Gold Mine (Uzbekistan), 3. Carlin-Nevada Complex (Nevada, Amerika Serikat), 4. Yanacocha Gold Mine (Peru), 5. Goldstrike (Betze Post) Gold Mine (Nevada, Amerika Serikat), 6. Cortez Gold Mine (Nevada, Amerika Serikat), 7. Veladero Gold Mine (Argentina), 8. Lagunas Norte Gold Mine (Peru), 9. Lihir Gold Mine (Papua New Guineau), 10. Super Pit/Kalgoorlie (Australia Barat). 
cadangan. Hal ini dapat dilihat dari data penemuan cadangan minyak baru sepanjang 2012 mencapai 164,28 juta barel, sementara jumlah minyak yang diproduksikan sebesar 329,9 juta barel. ${ }^{15}$ Indonesia harus membayar mahal impor minyak bumi yang dilakukan untuk memenuhi kebutuhan dalam negeri.

Berkenaan dengan hal tersebut di atas, maka penulis akan melakukan kajian mengenai liberalisasi perdagangan komoditas hasil sumber daya alam dengan adanya kewajiban pemenuhan kebutuhan dalam negeri atas hasil sumber daya alam. Adapun permasalahan yang akan dianalisis oleh penulis yaitu: Bagaimanakah pengaturan kewajiban pemenuhan kebutuhan dalam negeri atas komoditas sumber daya alam di Indonesia? dan Hambatan dan tantangan apa saja yang mungkin timbul atas kewajiban pemenuhan kebutuhan dalam negeri dalam rangka ketahanan nasional?

\section{B. METODE PENELITIAN}

Metode penelitian dalam kajian ini yaitu metode penelitian hukum normatif. Metode penelitian hukum normatif adalah suatu proses untuk menemukan suatu aturan hukum, prinsipprinsip hukum, maupun doktrin-doktrin hukum guna menjawab isu hukum yang dihadapi. ${ }^{16}$ Berkenaan dengan penelitian hukum normatif tersebut maka jenis dan sumber data yang digunakan yaitu jenis data sekunder yang dilakukan dengan studi pustaka terhadap bahan-bahan hukum dan bahan non-hukum.

Teknik pengumpulan data dalam kajian ini yaitu melalui studi dokumen atau studi bahan pustaka (library research). Adapun teknik pengolahan data dilakukan melalui tahapan pengolahan data dan bahan hukum yang dikumpulkan. Selanjutnya data dan bahan hukum diolah sedemikian rupa sehingga data dan bahan hukum tersebut tersusun secara runtut dan sistematis ke dalam klasifikasi yang sama atau yang dianggap sama, sehingga memudahkan penulis dalam melakukan analisis.

Dalam penelitian ini, peneliti menggunakan metode analisis data dengan pendekatan perundang-undangan, pendekatan konsep, dan pendekatan analisis ${ }^{17}$ yang dituangkan secara deskriptif dengan sifat analisis kualitatif.

\section{PEMBAHASAN}

\section{Pengaturan Kewajiban Pemenuhan Kebutuhan Sumber Daya Alam Dalam Negeri}

\section{a. Undang-Undang Nomor 41 Tahun 1999 tentang Kehutanan}

Undang-Undang Nomor 41 Tahun 1999 tentang Kehutanan (selanjutnya disebut UU Kehutanan) mengatur mengenai pemasaran hasil hutan. Pemasaran hasil hutan tersebut akan sangat terkait dengan kegiatan pemenuhan kebutuhan dalam negeri. Hasil hutan yang diambil dari kawasan hutan setelah dipanen, diolah, kemudian dipasarkan. Pemasaran tersebut dilakukan baik di dalam negeri maupun dalam rangka ekspor. Apabila hasil hutan tersebut dimanfaatkan untuk keperluan ekspor maka terkait dengan bagaimana kegiatan ekspor tersebut juga memperhatikan kepentingan dalam negeri, terutama pasokan atau kebutuhan dalam negeri.

\footnotetext{
PGN Inside, "Pengelolaan Sumber Daya Alam Strategis, majalah, edisi khusus 59,2013, hlm.4.

16 Peter Mahmud Marzuki, Penelitian Hukum, (Jakarta: Kencana, 2010), hlm. 35.

$17 \quad$ Ibid, hlm. 93.
} 
Dalam Pasal 33 ayat (1) UU Kehutanan diatur bahwa usaha pemanfaatan hasil hutan meliputi kegiatan penanaman, pemeliharaan, pemanenan, pengolahan, dan pemasaran hasil hutan. Selanjutnya pemanenan dan pengolahan hasil hutan tidak boleh melebihi daya dukung hutan secara lestari. ${ }^{18}$ Berdasarkan ketentuan tersebut UU Kehutanan hanya mengatur mengenai pemasaran sebagai bagian dari usaha pemanfaatan hasil hutan dan tidak mengatur mengenai adanya kewajiban pemenuhan kebutuhan dalam negeri apabila hasil hutan tersebut akan diekspor.

Ketentuan lebih lanjut mengenai pemasaran hasil hutan tersebut terdapat dalam Peraturan Pemerintah Nomor 6 Tahun 2007 tentang Tata Hutan dan Penyusunan Rencana Pengelolaan Hutan, serta Pemanfaatan Hutan (selanjutnya disebut PP 6 Tahun 2007) sebagaimana telah diubah dengan Peraturan Pemerintah Nomor 3 Tahun 2008 tentang Perubahan Atas Peraturan Pemerintah Nomor 6 Tahun 2007 tentang Tata Hutan dan Penyusunan Rencana Pengelolaan Hutan, serta Pemanfaatan Hutan (selanjutnya disebut PP 3 Tahun 2008).

Dalam Pasal 117 ayat (1) PP 6 Tahun 2007 diatur bahwa dalam rangka melindungi hak negara atas hasil hutan dan kelestarian hutan, dilakukan pengendalian dan pemasaran hasil hutan melalui penatausahaan hasil hutan. Selanjutnya semua hasil hutan yang berasal dari hutan negara, dilakukan penetapan jenis, pengukuran volume/berat, dan/atau penghitungan jumlah oleh petugas yang berwenang. ${ }^{19}$ Semua hasil hutan yang berasal dari hutan negara dapat dilakukan pengujian oleh petugas yang berwenang. ${ }^{20}$ Selanjutnya terhadap fisik hasil hutan berupa kayu bulat yang telah dilakukan kegiatan dilakukan penandaan. ${ }^{21}$ Dalam Pasal 118 PP 6 Tahun 2007, diatur lebih lanjut bahwa semua hasil hutan yang berasal dari hutan hak, dilakukan penetapan jenis, pengukuran volume/berat, dan penghitungan jumlah serta dilengkapi dengan surat keterangan asal usul hasil hutan hak yang ketentuan lebih lanjut mengenai penetapan jenis, pengukuran volume/berat, penghitungan jumlah serta surat keterangan asal usul hasil hutan hak diatur dengan peraturan Menteri Kehutanan. Setiap pengangkutan, penguasaan atau pemilikan hasil hutan yang berasal dari hutan negara, wajib dilengkapi bersama-sama dengan dokumen ${ }^{22}$ yang merupakan surat keterangan sahnya hasil hutan, yang berlaku dan dipergunakan untuk mengangkut hasil hutan di dalam wilayah Republik Indonesia. ${ }^{23}$ Menteri Kehutanan berwenang mengatur, membina dan mengembangkan pemasaran hasil hutan kayu dan bukan kayu yang belum diolah ke pasar dalam negeri dan industri primer hasil hutan sebagai bahan baku. ${ }^{24}$

18 Pasal 33 ayat (2) Undang-Undang Nomor 41 Tahun 1999 tentang Kehutanan.

19 Pasal 117 ayat (2) Peraturan Pemerintah Nomor 6 Tahun 2007 tentang Tata Hutan dan Penyusunan Rencana Pengelolaan Hutan, serta Pemanfaatan Hutan.

20 Pasal 117 ayat (3), Ibid.

21 Pasal 117 ayat (4), Ibid.

22 Dokumen harus sesuai dengan fisik hasil hutan yang diangkut. Kesesuaian fisik hasil hutan mempertimbangkan hasil pengukuran penguji dan hasil pengukuran oleh pengawas penguji. Dalam hal hasil pengukuran penguji dan hasil pengukuran pengawas penguji terdapat perbedaan, maka perbedaan tidak boleh melebihi toleransi yang ditetapkan Standar Nasional Indonesia. (Lihat Pasal 120 Peraturan Pemerintah Nomor 3 Tahun 2008).

23 Pasal 119 Peraturan Pemerintah Nomor 6 Tahun 2007 tentang Tata Hutan dan Penyusunan Rencana Pengelolaan Hutan, serta Pemanfaatan Hutan.

24 Pasal 121 ayat (1), Ibid. 
Selain pengaturan, pembinaan dan pengembangan pemasaran hasil hutan kayu dan bukan kayu, kewenangannya berada pada menteri yang bertanggung jawab di bidang perdagangan dengan memperhatikan pertimbangan Menteri Kehutanan. ${ }^{25}$ Berdasarkan ketentuan di bidang kehutanan tersebut terdapat pengaturan mengenai pengendalian dan pemasaran hasil hutan, namun tidak terdapat pengaturan mengenai kewajiban pemenuhan kebutuhan dalam negeri atas hasil hutan yang dipasarkan, termasuk pemasaran eskpor.

Dengan demikian, peraturan di bidang kehutanan yaitu di UU Kehutanan dan peraturan pelaksaannya tidak mengatur mengenai kewajiban pemenuhan kebutuhan dalam negeri atas hasil/produksi hutan yang dipasarkan dalam rangka ekspor.

\section{b. Undang-Undang Nomor 22 Tahun 2001 tentang Minyak dan Gas Bumi}

Dalam Pasal 3 huruf c Undang-Undang Nomor 22 Tahun 2001 tentang Minyak dan Gas Bumi (selanjutnya disebut UU Migas) diatur bahwa penyelenggaraan kegiatan usaha minyak dan gas bumi bertujuan menjamin efisiensi dan efektivitas tersedianya minyak bumi dan gas bumi, baik sebagai sumber energi maupun sebagai bahan baku, untuk kebutuhan dalam negeri. Pasal 3 huruf $c$ tersebut secara eksplisit mengatur mengenai adanya tujuan jaminan tersedianya minyak dan gas bumi untuk kebutuhan dalam negeri. Hal ini berbeda dengan UU Kehutanan yang tidak mengatur secara eksplisit dan implisit mengenai jaminan pemenuhan akan kebutuhan dalam negeri atas hasil hutan. Perbedaan tersebut dapat dipahami mengingat bahwa kebutuhan akan minyak dan gas bumi merupakan kebutuhan dasar bagi kehidupan manusia.

Mesin-mesin untuk industri, tranportasi, dan tenaga listrik digerakkan oleh bahan bakar yang bersumber dari salah satunya minyak dan gas bumi. Kebutuhan akan bahan bakar minyak dan gas bumi bersifat terus menerus, padahal ketersediaanya sangat terbatas. Minyak dan gas bumi yang telah diolah dan dimurnikan dapat dikonsumsi oleh masyarakat baik berupa bahan bakar minyak dan bahan bakar gas, termasuk liquefied natural gas, maupun produk berupa pelumas, aspal, lilin, dan produk petrokimia lainnya. Tanpa adanya produk hasil olahan dan permunian tersebut, maka aktifitas hidup masyarakat akan lumpuh karena sumber energi dan industri utamanya tidak tersedia.

Dalam UU Migas, pengaturan mengenai kebutuhan dalam negeri tertuang dalam Pasal 8 UU Migas, yaitu Pemerintah memberikan prioritas terhadap pemanfaatan gas bumi untuk kebutuhan dalam negeri dan bertugas menyediakan cadangan strategis minyak bumi guna mendukung penyediaan bahan bakar minyak dalam negeri yang diatur lebih lanjut dengan peraturan pemerintah. Selanjutnya, diatur bahwa Pemerintah wajib menjamin ketersediaan dan kelancaran pendistribusian bahan bakar minyak yang merupakan komoditas vital dan menguasai hajat hidup orang banyak di seluruh wilayah Negara Kesatuan Republik Indonesia. ${ }^{26}$

Bruce Ackermann and James S. Fishkin, op.cit., hlm. 146.

26 Pasal 8 ayat (2) Undang-Undang Nomor 22 Tahun 2001 tentang Minyak dan Gas Bumi. 
Berdasarkan ketentuan Pasal 8 UU Migas tersebut dapat diketahui bahwa pembuat undang-undang memahami bahwa ketersediaan bahan bakar dalam negeri merupakan suatu hal yang tidak dapat dihindari bahkan menjadi prioritas melalui upaya pemanfaatan gas bumi yang masih banyak tersedia dan upaya penyediaan cadangan strategis minyak bumi yang saat ini tidak terlalu banyak ditemukan. Penyediaan minyak bumi masih sangat tergantung sumur-sumur lama dan terus menurun produktifitasnya sehingga dalam rangka pemenuhan kebutuhan dalam negeri pun, Pemerintah harus melakukan impor. Di sektor hilir pun, Pemerintah harus menjamin ketersediaan dan kelancaran pendistribusian bahan bakar minyak yang dilakukan oleh Badan Pengatur Hilir Minyak dan Gas Bumi (BPH Migas).

Pemenuhan akan kebutuhan dalam negeri pun diatur pula dalam Pasal 11 ayat (3) huruf $g$ UU Migas, yaitu bahwa kontrak kerja sama wajib memuat paling sedikit ketentuan-ketentuan pokok yaitu: g. kewajiban pemasokan minyak bumi dan/atau gas bumi untuk kebutuhan dalam negeri. Pasal inilah yang mengatur secara jelas dan tegas mengenai kewajiban pemenuhan kebutuhan dalam negeri atas minyak bumi dan/ atau gas bumi. Setiap kontrak kerja sama antara Badan Pelaksana Migas (sekarang Satuan Kerja Khusus Migas) dengan kontraktor harus ada klausula mengenai kewajiban pamasokan minyak bumi dan/atau gas bumi untuk kebutuhan dalam negeri.
Besaran kewajiban pemenuhan kebutuhan dalam negeri tersebut diatur dalam Pasal 22 ayat (1) UU Migas, yaitu: "Badan Usaha atau Bentuk Usaha Tetap ${ }^{27}$ wajib menyerahkan paling banyak 25\% (dua puluh lima persen) bagiannya dari hasil produksi minyak bumi dan/atau gas bumi untuk memenuhi kebutuhan dalam negeri". Terhadap ketentuan paling banyak 25\% (dua puluh lima persen) tersebut telah dilakukan uji materiil ke Mahkamah Konstitusi dalam perkara nomor 022/PUU-1/2003.

Pemohon uji materiil menganggap Pasal 22 ayat (1) UU Migas ini akan berpotensi merugikan bangsa Indonesia karena kontraktor akan mendapatkan harga minyak dan gas bumi yang lebih mahal di luar Indonesia dibandingkan pasar dalam negeri, kontraktor pasti akan memilih menjual minyak dan gas bumi dengan porsi lebih besar ke luar negeri dengan hanya menyerahkan bagian terkecil, misalnya hanya $0,1 \%$ (nol koma satu persen) mengingat ketentuan dalam Pasal 22 ayat (1) UU Migas frasa yang tertulis "menyerahkan paling banyak 25\% (dua puluh lima persen)" artinya secara yuridis apabila kontraktor hanya menyerahkan $0,1 \%$ (nol koma satu persen) bukanlah hal yang dilarang undang-undang. Dalam Putusannya, Mahkamah Konstitusi menyatakan frasa sepanjang "paling banyak" bertentangan dengan Undang-Undang Dasar Negara Republik Indonesia 1945 dan dinyatakan tidak memiliki kekuatan hukum mengikat.

Pasal 28 ayat (1) Migas mengatur bahan bakar minyak serta hasil olahan tertentu yang dipasarkan di dalam negeri untuk memenuhi 
kebutuhan masyarakat wajib memenuhi standar dan mutu yang ditetapkan oleh Pemerintah. Melalui Putusan Mahkamah Konstitusi tersebut, maka kontraktor wajib menyerahkan $25 \%$ (dua puluh lima persen) bagiannya dari hasil produksi minyak bumi dan/atau gas bumi untuk memenuhi kebutuhan dalam negeri.

Berdasarkan hal tersebut, dalam rezim minyak dan gas bumi, kewajiban pemenuhan minyak dan gas bumi untuk kebutuhan dalam negeri secara tegas diatur dalam UU Migas. Bahkan hal tersebut dipertegas oleh Mahkamah Konstitusi dengan Putusan Nomor Perkara 022/PUU-I/2003 yang memberikan putusan bahwa besaran kewajiban penyerahan KPS hasil produksi minyak bumi dan/atau gas bumi untuk memenuhi kebutuhan dalam negeri sebesar $25 \%$ (dua puluh lima persen) bagiannya secara tetap.

\section{c. Undang-Undang Nomor 4 Tahun 2009 tentang Pertambangan Mineral dan Batubara}

Undang-Undang Nomor 4 Tahun 2009 tentang Pertambangan Mineral dan Batubara (selanjutnya disingkat UU Minerba) merupakan salah satu undang-undang di bidang sumber daya alam, khususnya energi dan sumber daya mineral yang sangat terkait dengan hajat hidup orang banyak. Pasal 33 ayat (3) UUD NRI 1945 menegaskan bahwa bumi, air, dan kekayaan alam yang terkandung di dalamnya dikuasai oleh negara dan dipergunakan untuk sebesarbesar kemakmuran rakyat.

Dalam Pasal 3 huruf c UU Minerba diatur bahwa dalam rangka mendukung pembangunan nasional yang berkesinambungan, tujuan pengelolaan mineral dan batubara adalah menjamin tersedianya mineral dan batubara sebagai bahan baku dan/atau sebagai sumber energi untuk kebutuhan dalam negeri. Selanjutnya dalam Pasal 5 UU Minerba diatur:

(1) Untuk kepentingan nasional, Pemerintah setelah berkonsultasi dengan Dewan Perwakilan Rakyat Republik Indonesia dapat menetapkan kebijakan pengutamaan mineral dan/atau batubara untuk kepentingan dalam negeri.

(2) Kepentingan nasional sebagaimana dimaksud pada ayat (1) dapat dilakukan dengan pengendalian produksi dan ekspor.

(3) Dalam melaksanakan pengendalian sebagaimana dimaksud pada ayat (2), Pemerintah mempunyai kewenangan untuk menetapkan jumlah produksi tiap-tiap komoditas per tahun setiap provinsi.

(4) Pemerintah daerah wajib mematuhi ketentuan jumlah yang ditetapkan oleh Pemerintah sebagaimana dimaksud pada ayat (3).

(5) Ketentuan lebih lanjut mengenai pengutamaan mineral dan/atau batubara untuk kepentingan dalam negeri sebagaimana dimaksud pada ayat (1) dan pengendalian produksi dan ekspor sebagaimana dimaksud pada ayat (2) dan ayat (3) diatur dengan peraturan pemerintah.

Berdasarkan ketentuan tersebut diatas, maka rezim pengaturan mineral dan batubara secara eksplisit menyatakan pentingnya pemenuhan kebutuhan dalam negeri atas mineral dan batubara. Melalui pemenuhan kebutuhan dalam negeri tersebut untuk kepentingan nasional maka ekspor dan penjualan dapat dikendalikan. Bahkan Pemerintah dapat menetapkan jumlah produksi tiap-tiap komoditas pertahun setiap provinsi sebagai bentuk pengendalian ekspor dan penjualan.

Ketentuan mengenai kewajiban pemenuhan kebutuhan dalam negeri di UU Minerba diatur 
lebih lanjut dalam Peraturan Pemerintah Nomor 23 Tahun 2010 tentang Kegiatan Usaha Pertambangan Mineral dan Batubara sebagaimana telah diubah dengan Peraturan Pemerintah Nomor 1 Tahun 2014 tentang Perubahan Kedua Atas Peraturan Pemerintah Nomor 23 Tahun 2010 tentang Kegiatan Usaha Pertambangan Mineral dan Batubara.

Dalam Pasal 2 Peraturan Pemerintah Nomor 23 Tahun 2010 tentang Kegiatan Usaha Pertambangan Mineral dan Batubara (selanjutnya disebut PP 23 Tahun 2010) diatur bahwa pelaksanaan kegiatan usaha pertambangan mineral dan batubara ditujukan untuk melaksanakan kebijakan dalam mengutamakan penggunaan mineral dan/atau batubara untuk kepentingan dalam negeri. ${ }^{28}$ Adapun lingkup PP 23 Tahun 2010 meliputi pemberian izin usaha pertambangan (IUP), Izin pertambangan rakyat (IPR), dan izin usaha pertambangan khusus (IUPK), kewajiban pemegang IUP, IPR, dan IUPK, serta pengutamaan penggunaan mineral logam dan/ atau batubara untuk kepentingan dalam negeri.

Selanjutnya dalam Pasal 84 dinyatakan bahwa:

(1) Pemegang IUP Operasi Produksi dan IUPK Operasi Produksi harus mengutamakan kebutuhan mineral dan/atau batubara untuk kepentingan dalam negeri.

(2) Menteri menetapkan kebutuhan mineral dan batubara di dalam negeri sebagaimana dimaksud pada ayat (1) meliputi kebutuhan untuk industri pengolahan dan pemakaian langsung di dalam negeri.
(3) Pemegang IUP Operasi Produksi dan IUPK Operasi Produksi dapat melakukan ekspor mineral atau batubara yang diproduksi setelah terpenuhinya kebutuhan mineral dan batubara dalam negeri sebagaimana dimaksud pada ayat (1)

(4) Ketentuan lebih lanjut mengenai tata cara pengutamaan kebutuhan mineral dan batubara untuk kepentingan dalam negeri diatur dengan Peraturan Menteri.

Dalam hal ini UU Minerba dan PP 23 Tahun 2010 telah mengatur kewajiban pemenuhan kebutuhan di dalam negeri. Namun, dalam kedua aturan tersebut tidak diatur besaran atau persentase mengenai kewajiban pemenuhan kebutuhan dalam negeri oleh setiap pemegang IUP dan IUPK.

UU Minerba telah mewajibkan pemenuhan kebutuhan dalam negeri sebelum hasil tambang mineral dan batubara di ekspor. Namun hingga saat ini belum ada upaya sistematis dari pemerintah untuk meningkatkan kewajiban pemenuhan kebutuhan dalam negeri antara lain melalui sinergi dengan sektor hilir yang menyerap bahan tambang sebagai bahan bakunya. ${ }^{29} \mathrm{Hal}$ ini menyebabkan sebagian besar barang tambang mineral dan batubara di ekspor ke luar negeri.

Selain, undang-undang tersebut di atas, ada pula Undang-Undang Nomor 21 tahun 2014 tentang Panas Bumi (selanjutnya disebut UU Panas Bumi). Terkait dengan pemenuhan kebutuhan dalam negeri, secara teknis panas bumi bukanlah produk yang dapat diekspor

\footnotetext{
28 Pasal 2 ayat (2) Peraturan Pemerintah Nomor 23 Tahun 2010 tentang Kegiatan Usaha Pertambangan Mineral dan Batubara.

29 Sekretariat Kabinet RI, "Gerakan Nasional Penyelematan Sumber Daya Alam Sektor Kelautan, Pertambangan, Kehutanan, dan Perkebunan”, http://setkab.go.id/wp-content/uploads/2015/03/GN-SDA-2015-Lampiran-1Final.pdf, (diakses 10 Agustus 2015), hlm. 8.
} 
karena sifat panas bumi yang saat ini belum bisa ditampung dalam sebuah wadah. Bila gas alam bias dicairkan dalam tabung dengan tekanan tertentu, panas bumi (uap air) bila dikondensasi hasilnya hanya berupa air. Panas bumi yang ada dalam perut bumi dengan suhu tinggi menghasilkan uap panas yang selanjutnya akan dialirkan untuk menggerakkan turbin yang selanjutnya memutar generator yang akan menggubah energi kinetik menjadi energi listrik. Listrik tersebut didistribusikan dan ditransmisikan untuk kepentingan umum.

Selain Undang-Undang tersebut di atas, Undang-Undang Nomor 39 Tahun 2014 tentang Perkebunan juga merupakan undang-undang di sektor sumber daya alam. Namun, UndangUndang ini tidak mengatur mengenai kewajiban pemenuhan kebutuhan dalam negeri atas produk perkebunan. Selanjutnya UndangUndang Nomor 18 Tahun 2012 tentang Pangan (selanjutnya disingkat UU Pangan) pun juga merupakan undang-undang yang menyangkut sumber daya alam karena pangan merupakan segala sesuatu yang berasal dari sumber hayati produk pertanian, perkebunan, kehutanan, perikanan, peternakan, perairan, dan air baik yang diolah maupun tidak diolah yang diperuntukkan sebagai minuman makanan atau minuman bagi konsumsi manusia. ${ }^{30}$

UU Pangan mengatur mengenai ketersediaan pangan sebagaimana diatur dalam Pasal 12 sampai dengan Pasal 15. Selain itu, diatur pula mengenai prosuksi pangan dalam negeri, termasuk ekspor pangan yang dapat dilakukan dengan memperhatikan kebutuhan konsumsi di dalam negeri dan kepentingan nasional. ${ }^{31}$
Ekspor pangan hanya dapat dilakukan setelah terpenuhinya kebutuhan konsumsi pangan pokok dan cadangan pangan nasional. ${ }^{32}$

Berdasarkan pengaturan beberapa undangundang tersebut di atas, tampak secara jelas bagaimana politik hukum pembuat undangundang dalam upaya kebijakan pemenuhan kebutuhan di dalam negeri atas produk atau hasil sumber daya alam di Indonesia dalam rangka ketahanan nasional.

\section{Hambatan dan Tantangan}

Dalam pelaksanaan pemenuhan kebutuhan dalam negeri atas sumber daya alam tentunya akan terdapat beberapa hambatan. Adapun hambatan tersebut antara lain:

\section{a. Hambatan Regulasi}

Sebagaimana dibahas terdahulu bahwa peraturan perundang-undangan yang mengatur mengenai pemenuhan kebutuhan dalam negeri atas hasil sumber daya alam beragam. Beberapa hambatan regulasi terkait hal tersebut, misalnya mengenai subjek yang bertanggung jawab melaksanakan pemenuhan kebutuhan dalam negeri. Ada undang-undang yang mengatur secara rinci mengenai kewajiban pemenuhan kebutuhan dalam negeri atas hasil sumber daya alam kepada pelaku usaha, ada pula peraturan perundang-undangan yang mewajibkan pemenuhan kebutuhan dalam negeri akan hasil sumber daya alam kepada Pemerintah dan pemerintah daerah.

Selain itu, tidak semua peraturan perundangundangan yang mengatur mengenai kewajiban

Pasal 1 angka 1 Undang-Undang Nomor 18 Tahun 2012 tentang Pangan.

Pasal 34 ayat (1), Ibid.

Pasal 34 ayat (2), Ibid. 
pemenuhan kebutuhan dalam negeri, misalnya UU Kehutanan yang hanya mengatur mengenai pemasaran termasuk ekspor namun tidak diatur mengenai adanya kewajiban bagi pelaku usaha untuk terlebih dahulu memenuhi kebutuhan produksi/hasil hutan di dalam negeri. Hambatan lainnya, misalnya adanya pengaturan mengenai kewajiban pemenuhan kebutuhan dalam negeri atas mineral dan batubara sebagai wujud pengendalian, namun Peraturan Menteri Energi dan Sumber Daya Mineral mengenai pengendalian penjualan dan ekspor tidak kunjung terbit.

\section{b. Hambatan Implementasi}

Hambatan kedua yaitu hambatan implementasi atas peraturan perundangundangan. Hukum tidak hanya dimaknai sebagai law in the books tetapi juga sebagai law in action. Misalnya sebagaimana diungkapkan oleh Misuzu Otsuka, Stephen Thomsen, dan Andrea Goldstein bahwa: ${ }^{33}$

"Economic and political uncertainty was once considered one of investors' greatest concerns. After a long period of difficult political and economic transformation, Indonesia's investment environment has greatly improved and the rules of the game have become more predictable. A number of new laws and regulations have been introduced to clarify rules for investors, of which the Investment Law of 2007 is the most important".

Ada beberapa pengaturan yang tidak dapat diimplementasikan secara baik, misalnya menyangkut kewajiban pemenuhan 25\% (dua puluh lima persen) hasil produksi minyak dan/ atau gas bumi kontraktor untuk kebutuhan dalam negeri. Dalam realitas, Indonesia yang saat ini mengalami defisit produksi untuk memenuhi kebutuhan dalam negeri tidak terdampak atas kewajiban tersebut. Walaupun $100 \%$ (seratus persen) hasil produksi di blok minyak bumi disediakan untuk kebutuhan dalam negeri oleh badan usaha milik negara ditambah dengan kewajiban $25 \%$ (dua puluh lima persen) kontraktor maka kebutuhan dalam negeri Indonesia relatif belum juga dapat dipenuhi.

Hambatan implementasi lainnya, misalnya mengenai pengendalian ekspor dan penjualan mineral dan batubara yang saat ini tidak dapat direalisasikan. Padahal UU Minerba telah terbentuk lebih dari 5 (lima) tahun, namun kebijakan pengendalian tersebut belum juga terlaksana. Padahal melalui kebijakan tersebut produksi, penjualan, dan ekspor dapat dikendalikan agar eksploitasi besar-besaran sumber daya alam tidak terjadi secara masif.

Belum lagi persoalan akibat eksploitasi sumber daya alam terhadap kerusakan lingkungan. Di kawasan hutan, kerusakan hutan dan hilangnya keanekaragaman hayati terjadi karena: ${ }^{34}$

1) increased demand for raw materials;

2) increased dependency on natural forests due to improper management of industrial forestry;

3) increase in rate of degradation and deforestation, not only to natural forests but also to cultivated/industrial forests due

\footnotetext{
33 Misuzu Otsuka, Stephen Thomsen, dan Andrea Goldstein, "Improving Indonesia's Investment Climate", Organisation for Economic Co-operation and Development Investment Insights Februari 2011-Issue 1, hlm.4.

34 United Nations Environment Programme, "Sustainable Use of Natural Resources in the Context of Trade Liberalization andExport Growth in Indonesia A Study on the Use of Economic Instruments in the Pulp and Paper Industry", diakses http://www.unep.ch/etb/publications/Indonesia.pdf pada (diakses 10 Agutus 2015).
} 
to increase in ille gal logging when supply of raw materials is low;

4) deterioration of forest ecosystems, threats to biodiversity and loss of endemic species;

5) social impacts due to destruction of local communities sur rounding and/or within the forest.

\section{c. Hambatan Kapasitas}

Dalam konteks hambatan kapasitas, ditekankan pada pihak yang terlibat dalam pemenuhan kebutuhan dalam negeri atas sumber daya alam. Hambatan kapasitas akan sangat beragam, mulai dari kapasitas Pemerintah dan pemerintah daerah serta pelaku usaha yang dikenai kewajiban pemenuhan kebutuhan dalam negeri atas hasil sumber daya alam. Sebagai contoh kapasitas pemerintah yang menghambat pelaksanaan pemenuhan kebutuhan dalam negeri atas sumber daya alam, yaitu belum diterbitkannya aturan mengenai kewajiban pemenuhan kebutuhan dalam negeri bagi perusahaan pertambangan mineral dan batubara. Saat ini, perusahaan pertambangan mineral dan batubara dapat melakukan penjualan atas hasil tambangnya secara bebas bahkan ketika terdapat larangan ekspor atas mineral mentah oleh UU Minerba, perusahaan pertambangan tetap melakukan ekspor mineral mentah atau konsentrat keluar negeri.

Fakta tersbut di atas menjadi hambatan kapasitas baik pemerintah maupun pelaku usaha dalam rangka kewajiban pemenuhan kebutuhan dalam negeri atas mineral Indonesia.
Selain hambatan tersebut, terdapat pula tantangan pemenuhan kebutuhan dalam negeri, yaitu:

\section{a. Perkembangan Liberalisasi Perdagangan di Indonesia}

Liberalisasi perdagangan sumber daya alam akan sangat dipengaruhi oleh keadaaan geografis. Sebagai contoh ketersediaan minyak bumi dunia 90\% (sembilan puluh persen) dikuasai hanya oleh 15 (lima belas) negara. Sebagaimana disampaikan oleh Michele Ruta dari World Trade Organisation dan Anthony J. Venables bahwa: ${ }^{3}$

"Trade in natural resources has a number of features that make it distinctive and which bear on policy in the sector. Uneven geographical distribution of resources means that some countries are dominated by resource production, while others have none; more than $90 \%$ of proven oil reserves are in just 15 countries. Resource supplies are immobile, so incentives to use policy to relocate production are largely absent. Exhaustible resources may carry large rents, and the division of these rents between producers and consumers is contentious".

Kebutuhan dalam negeri tiap-tiap negara tentunya akan bergesekan dengan pelaksanaan liberalisasi perdagangan tersebut. Secara teoritis, agenda utama liberalisasi perdagangan adalah mereduksi hambatan perdagangan baik untuk barang, jasa, hak milik intelektual, dan investasi. Liberalisasi tersebut dalam implementasinya, menempatkan Indonesia menjadi negara dengan posisi: (1) tempat mendapatkan bahan mentah atau bahan baku 
industri; (2) tempat penanaman modal asing; (3) tempat mendapatkan tenaga kerja yang murah; dan (4) menjadi tempat pemasaran barang-barang produksi negara-negara industri.

Terkait dengan posisi Indonesia sebagai tempat mendapatkan bahan mentah atau bahan baku industri, sesuai dengan karakteristrik sumber daya alam yang melakat pada tanah atau lahan suatu wilayah sehingga tidak dapat dipindah-pindahkan. Perusahaan yang berminat untuk mengeksplorasi atau eksploitasi maka harus melakukan eksplorasi dan eksploitasi ke tempat keberadaan sumber daya alamnya tersebut. Hal tersebut sebagaimana diungkapkan oleh John P. Williams:

\begin{abstract}
"As mining is local, it may, and often does, lead to enclave development rather than general economic development. This raises various equity and policy issues because the positive and negative direct impacts of mining affect $a$ local area and population disproportionately. Mining invariably requires dealing with major environmental, social and health challenges. Under the current understanding of international best practice, in addition to assessing and mitigating or remediating negative impacts on the local natural and social environment, mining companies also have the responsibility to plan for and contribute to the sustainable development of the local economy in the area where the mine is located after it closes". 36
\end{abstract}

Dengan posisi Indonesia tersebut, maka liberalisasi perdagangan di Indonesia menjadi tantangan tersendiri. Kebijakan Pemerintah harus menempatkan posisi Indonesia tersebut memiliki manfaat yang besar bagi kepentingan nasional dan sesuai prinsip kedaulatan negara yang harus diakui, diformulasikan, dan dipatuhi. ${ }^{37}$ Misalnya posisi Indonesia sebagai tempat mendapatkan bahan mentah atau bahan baku industri harus diubah menjadi Indonesia sebagai bagian negara Industri berdasarkan potensi bahan mentah di dalam negeri.

Indonesia harus malakukan ekspor atas produk yang sudah diolah bukan lagi bahan mentah, karena dengan peningkatan menjadi produk olahan maka Indonesia akan memperoleh nilai tambah produk, penyerapan tenaga kerja, dan penerimaan negara.

\section{b. Komodifikasi Sumber Daya Alam}

Di berbagai dunia, misalnya Iran yang memiliki kekayaan alam berupa minyak bumi, perkembangan pengurusannya mengalami dinamika.

"Industry and mining section have involved
effective during $1961-1968$ in Iran's economic
development. In 1970 industry prospered in
Highlevel by government's support of industry
and donations industrial Bank and increasing
investment. Hence growth in industry and
mining sector reached to 13.8 percent. Value
added growth in industry and mining section
reached to the 13.5 percent in 1971 and
was more than predicted goal in the fourth
development plan. With widespread strikes
in 1998, industrial and mining activities was
decreased too much, therefore economic in
Iran was faced with the relative stagnation by
the Islamic Revolution and problems such as
shortages of imported raw materials in small
industries. In despite of these conditions the
added value in industry and mining section
increased about 5.1 percent". 38

36 John P. Williams, "International Best Practice" In Mining Who Decides And How-And How Does It Impact Law Development?", Georgetown Journal of International Law Summer Vol. 39 Geo. J. Int'l L. 693 (2008), hlm. 1-2.

37 Huala Adolf, Hukum Ekonomi Internasional, cetakan ke-5, (Bandung: Penerbit Keni, 2010), hlm. 34.

38 Safdari Mehdi, Zaroki, Shahryar, "The Study Examining The Effect Of Export Growth On Economic Growth In Iran", Business Intelligence Journal, 2011. 
Begitu pula Indonesia yang pengusahaan sumber daya alam mengalami perubahan paradigma pengusahaan dari waktu ke waktu. Perubahan paradigma tersebut dipengaruhi oleh cara pandang penguasa pada masa kebijakan itu dibuat. Kebijakan usaha pertambangan pada tataran konsep memilih 2 (dua) paradigma dan implikasi berbeda, yaitu: ${ }^{39}$

1) Paradigma yang menilai bahwa sumber daya alam sebagai sumber pendapatan ketimbang modal. Eksploitasi sumber daya alam hanya diarahkan untuk mendukung pertumbuhan ekonomi tanpa memperhatikan secara proposional kelestarian fungsi lingkungan hidup dalam batas-batas tertentu keberadaan industri pertambangan dalam suatu wilayah kerja, bukan hanya menempatkan diri sebagai entitas asing tetapi juga merupakan prahara/masalah sosial.

2) Paradigma yang memandang bahwa usaha pertambangan merupakan industri modern. Tanpa produk pertambangan berupa logam dan mineral, manusia kembali dalam zaman batu.

Paradigma tersebut mempengaruhi kebijakan komodifikasi sumber daya alam. Kebijakan sumber daya alam dijadikan komoditas untuk memperoleh manfaat ekonomi atau tidak sangat dipengaruhi oleh paradigma. Sebagai contoh, saat ini hasil sumber daya alam berupa panas bumi bukan menjadi komoditas ekspor namun di masa mendatang dapat saja panas bumi menjadi komoditas ekspor ketika ditemukan teknologi yang dapat menampung uap air panas bumi.
Komodifikasi hasil sumber daya alam untuk memperoleh manfaat ekonomi sebanyakbanyak menjadi tantangan bagi Indonesia. Sumber daya alam tidak hanya dijadikan sebagai komoditas ekonomi (komodifikasi) namun perlu juga memperhatikan aspek cadangan sumber daya alam dan kepentingan perlindungan dan pengelolaan lingkungan hidup.

\section{c. Ketahanan Sumber Daya Alam Indonesia di Era Pasar Bebas}

Sebagaimana telah dijelaskan terdahulu bahwa liberalisasi melalui pasar bebas akan membuat batasan dan hambatan perdagangan berkurang bahkan hapus. Artinya negara-negara di dunia akan dapat mengakses pengusahaan sumber daya alam di manapun, di belahan bumi ini, termasuk Indonesia. Akses atas sumber daya alam di era pasar bebas berkaitan dengan teori ekonomi klasik Adam Smith dan David Ricardo. Adam Smith dan David Ricardo berpendapat bahwa perdagangan internasional memainkan peran penting dalam pertumbuhan ekonomi. Pendekatan neoklasik menekankan pentingnya keunggulan kompetitif dalam perdagangan internasional. Setiap negara memaksimalkan kesejahteraan melalui kegiatan yang paling efisien mengenai sumber daya dan produksi faktor kelangkaan ekonomi.

Sebagaimana disampaikan oleh Ruba Abu Shihab:
"It goes back to the classical economic theories by Adam Smith and David Ricardo, who argued that international trade plays an important role in economic growth. The neoclassical approach emphasizes the importance of competitive advantages in international trade. Each country maximizes 
its welfare through the activities which are the most efficient regarding resource and production factors scarcity in of economy. In this case, the benefits of the trade are static and trade liberation and openness can't lead to increase in long run growth rate, but it in fluences income level". ${ }^{40}$

Pengusahaan sumber daya alam dalam dimensi pasar bebas akan sangat berpengaruh pada ketahanan sumber daya alam negara tuan rumah. Negara tuan rumah yang memiliki sumber daya alam terutama sumber daya alam yang tidak dapat diperbarui, akan mendapatkan manfaat ekonomi melalui kegiatan pengusahaan tersebut. Namun konsekuensinya, negara tersebut akan kehilangan sumber daya alamnya. Untuk itu, cadagangan sumber daya alam negara tuan rumah, dalam hal ini Indonesia, harus diperhatikan. Apabila sumber daya alam tersebut habis tanpa tersisa maka ketahanan sumber daya alam akan mempengaruhi ketahanan nasional. Seperti saat ini, ketahanan nasional kita terganggu apabila pasokan minyak bumi tidak mampu memenuhi ketersediaan dalam negeri.

Hal ini menjadi tantangan berat bagi Indonesia agar pemenuhan kebutuhan dalam negeri menjadi prioritas dalam kegiatan liberalisasi perdagangan.

\section{PENUTUP}

Saat ini, Indonesia masih menjadi negara yang memiliki jumlah dan jenis sumber daya alam yang relatif kaya. Jumlah dan jenis yang kaya ini janganlah membuat Indonesia terlena untuk meliberalisasi secara besar-besaran baik liberalisasi perizinan/kontrak pengusahaan sumber daya alam melalui penanaman modal asing maupun liberalisasi hasil/produksi sumber daya alam melalui ekspor besar-besaran bahan mentah. Penanaman modal asing dan ekspor bahan mentah akan mempengaruhi ketahanan sumber daya alam Indonesia yang akan pula berdampak pada ketahanan nasional. Untuk itu, kebijakan kewajiban pemenuhan kebutuhan dalam negeri atas hasil/komoditas sumber daya alam menjadi jalan keluar atas gempuran liberalisasi ekonomi di Indonesia.

Menghadapi liberalisasi tersebut, realitas pengaturan kewajiban pemenuhan kebutuhan dalam negeri atas komoditas sumber daya alam di Indonesia masih belum sempurna. Walau telah terdapat berbagai perturan perundang-undangan yang 'peka' terhadap dampak liberalisasi tersebut dan menjadi early warning system regulation, namun tidak semua peraturan perundang-undangan di bidang sumber daya alam yang peka terhadap gempuran liberalisasi ekonomi tersebut bahkan ada peraturan perundang-undangan yang tidak mengatur hal demikian sama sekali. Sebagai contoh dalam UU Minerba dan PP 23 Tahun 2010 telah mengatur kewajiban pemenuhan kebutuhan di dalam negeri. Namun, dalam kedua aturan tersebut tidak diatur besaran atau persentase mengenai kewajiban pemenuhan kebutuhan dalam negeri oleh setiap pemegang IUP dan IUPK.

Berbeda dengan rezim minyak dan gas bumi sebagaimana diatur dalam Pasal $22 \mathrm{UU}$ Minerba yang mengatur mengenai kewajiban badan usaha atau bentuk usaha tetap wajib menyerahkan 25\% (dua puluh lima persen) bagiannya dari hasil produksi minyak bumi dan/

40 Ruba Abu Shihab, "The Causal Relationship between Exports and Economic Growth in Jordan”, International Journal of Business and Social Science, Vol. 5, No.3, Maret 2014, hlm. 302. 
atau gas bumi untuk memenuhi kebutuhan dalam negeri.

Pelaksanaan kebijakan pemenuhan kebutuhan dalam negeri atas hasil sumber daya alam dalam implementasinya mendapat hambatan dan tantangan. Hambatan tersebut antara lain hambatan regulasi, hambatan implementasi, dan hambatan kapasitas. Sedangkan tantangannya antara lain perkembangan liberalisasi perdagangan di Indonesia, komodifikasi sumber daya alam, dan ketahanan sumber daya alam di era pasar bebas.

Berdasarkan hal tersebut, sebaiknya pembuat kebijakan untuk: (1) mulai menentukan secara ketat komoditas/hasil sumber daya alam yang menjadi produk ekonomi dengan memperhatikaan ketersediaan dalam negeri dan cadangan untuk generasi yang akan datang; (2) mengurangi bahkan menghilangkan ekspor bahan mentah atas hasil sumber daya alam sehingga eksploitasi besar-besaran atas sumber daya alam yang mempengaruhi ketersediaan bahan mentah di dalam negeri; (3) komodifikasi sumber daya alam yang tidak dapat diperbarui dikurangi; (4) bersikap tegas kepada pelaku usaha untuk memenuhi kewajiban pemenuhan kebutuhan dalam negeri sesuai dengan amanat undang-undang di sektor bidang usahanya misalnya komoditas mineral; (5) membuat atau mengubah peraturan perundang-undangan di bidang sumber daya alam yang belum mengatur mengenai pembolehan kegiatan ekspor atas hasil sumber daya alam apabila telah terpenuhinya kebutuhan di dalam negeri.

\section{DAFTAR PUSTAKA}

\section{Buku}

Adolf, Huala Hukum Ekonomi Internasional, cetakan ke-5, (Bandung: Penerbit Keni, 2010)

Hasan, Madjedi, Kontrak Minyak dan Gas Bumi Berasas Keadilan dan Kepastian Hukum, (Jakarta: PT Fikahati Aneska, 2009)

Marzuki, Peter Mahmud, Penelitian Hukum, (Jakarta: Kencana, 2010)

Redi, Ahmad, Hukum Sumber Daya Alam Sektor Kehutanan, (Jakarta: PT Sinar Grafika, 2014)

Redi, Ahmad, Hukum Pertambangan, (Bekasi: PT Gramata Publishing, 2014)

Saleng, Abrar, Hukum Pertambangan, (Yogyakarta: UII Press, 2004)

\section{Makalah/Artikel/Prosiding/Hasil Penelitian}

Akinkugbe, O, "Flow of Foreign Direct Investment to Higher to Neglected Developing Countries," Discussion Paper No. 2003/02, World Institute for Development Economic Research (WIDER), United Nations Universtity (2003)

Auty, Richard M "Natural Resources, Development Models and Sustainable Development," Environmental Economics Programme. International Institute for Environment and Development (IIED), (Discussion Paper 03-01 June 2003)

Dima, Dima, "The Link Between Globalisation, Economic Growth and education: An Analysis In The Case Of Romania," Studia Universitatis Vasile Goldis, Arad Economics Series Vol 24 Issue 4 (2014)

Dutu, Ricard, "Making the Most of Natural Resources in Indonesia," OECD Economics Department Working Papers No. 1236, 28 May (2015)

International Monetary Fund, "Globalization: Threat or Oppurtunity," IMF Publication, 12 April (2002)

Mehdi, Safdari dan Zaroki, Shahryar, "The Study Examining The Effect Of Export Growth On Economic Growth In Iran," Business Intelligence Journal (2011)

Otsuka, Misuzu, dan Stephen Thomsen, dan Andrea Goldstein, "Improving Indonesia's Investment Climate," Organisation for Economic Cooperation and Development Investment Insights, Februari Issue 1 (2011)

PGN Inside, "Pengelolaan Sumber Daya Alam Strategis, majalah, edisi khusus 59, (2013) 
Ruta, Michele, dan AnthonyJ.Venables "International Trade in Natural Resources: Practice and Policy," Staff Working Paper ERSD-2012-07 World Trade Organization Economic Research and Statistics Division, (March 2012)

Saleng, Abrar, "Risiko-Risiko dalam Eksplorasi dan Eksploitasi Pertambangan serta Perlindungan Hukum Terhadap Para Pihak," Jurnal Hukum Bisnis, Volume 26-No.2 (2007)

Shihab, Ruba Abu, "The Causal Relationship between Exports and Economic Growth in Jordan," International Journal of Business and Social Science, Vol. 5, No.3, Maret (2014)

The Geotime Magazine, "Sengkarut Blok Mahakam," Vol 02 Nomor 16, 29 Juni-5 Juli (2015)

Tuca, Sabina, "The Evolution Of Economic Globalization During The Current Global Crisis," CES Working Papers (Volume V, Issue 4)

W, Khadduri, "Facilitating Investment in Energy Sector," (Paper Presentated to $8^{\text {th }}$ International energy Forum, September 21-23, 2002, Osaka, Japan. Middle East Economic Survey (MEES), 2002)

Williams, John P. "International Best Practice" In Mining Who Decides And How--And How Does It Impact Law Development?," Georgetown Journal of International Law Summer Vol. 39 Geo. J. Int'I L. 693 (2008)

\section{Internet}

Sekretariat Kabinet RI, "Gerakan Nasional Penyelematan Sumber Daya Alam Sektor Kelautan, Pertambangan, Kehutanan, dan Perkebunan," http://setkab.go.id/wp-content/ uploads/2015/03/GN-SDA-2015-Lampiran-1Final.pdf (diakses pada 10 Agustus 2015)

Tsen, Wong Hock, "Exports, Domestic Demand And Economic Growth In China: Granger Causality Analysis," http://www.karyiuwong.com/confer/ beijing06/papers/wong_ht.pdf (diakses 10 Agustus 2015)
United Nations Environment Programme, "Sustainable Use of Natural Resources in the Context of Trade Liberalization andExport Growth in Indonesia A Study on the Use of Economic Instruments in the Pulp and Paper Industry," http://www.unep.ch/etb/ publications/Indonesia.pdf pada (diakses 10 Agutus 2015)

\section{Peraturan}

Undang-Undang Dasar Negara Republik Indonesia Tahun 1945

Undang-Undang Nomor 39 Tahun 2014 tentang Perkebunan

Undang-Undang Nomor 21 Tahun 2014 tentang Panas Bumi

Undang-Undang Nomor 7 Tahun 2014 tentang Perdagangan

Undang-Undang Nomor 18 Tahun 2012 tentang Pangan

Undang-Undang Nomor 4 Tahun 2009 tentang Pertambangan Mineral dan Batubara

Undang-Undang Nomor 25 Tahun 2007 tentang Penanaman Modal.

Undang-Undang Nomor 22 Tahun 2001 tentang Minyak dan Gas Bumi

Undang-Undang Nomor 41 Tahun 1999 tentang Kehutanan

Peraturan Pemerintah Nomor 3 Tahun 2008 tentang Perubahan Atas Peraturan Pemerintah Nomor 6 Tahun 2007 tentang Tata Hutan dan Penyusunan Rencana Pengelolaan Hutan, serta Pemanfaatan Hutan

Peraturan Pemerintah Nomor 6 Tahun 2007 tentang Tata Hutan dan Penyusunan Rencana Pengelolaan Hutan, serta Pemanfaatan Hutan

Peraturan Presiden Nomor 36 Tahun 2014 tentang Daftar Bidang Usaha Yang Terbuka Dengan Persyaratan dan Daftar Usaha Yang Tertutup Dalam Penanaman Modal 